\title{
Salinity tolerance, ontogeny of osmoregulation and zootechnical improvement in the larval rearing of the Caledonian Blue Shrimp, Litopenaeus stylirostris (Decapoda, Penaeidae)
}

\author{
Dominique Pham ${ }^{\mathrm{a}, ~}{ }^{*}$, Guy Charmantier ${ }^{\mathrm{b}}$, Nelly Wabete ${ }^{\mathrm{a}}$, Viviane Boulo ${ }^{\mathrm{b}}$, Francis Broutoi ${ }^{\mathrm{a}}$, \\ Jean-René Mailliez ${ }^{a}$, Jean-Marie Peignon ${ }^{a}$, Mireille Charmantier-Daures ${ }^{b}$
}

\begin{abstract}
${ }^{a}$ Laboratoire Environnement et Aquaculture Durable, Ifremer, Boulouparis, Nouvelle-Calédonie
b Université Montpellier 2, Equipe Adaptation Ecophysiologique et Ontogenèse, UMR 5119, Ecosym, UM2, CNRS, IRD, Ifremer, Place Eugène Bataillon, CC 092, 34095 Montpellier, Cedex 05, France
\end{abstract}

*: Corresponding author : Dominique Pham, email address : $\underline{\text { dpham@ifremer.fr }}$

\begin{abstract}
:
The ontogeny of osmoregulation was investigated in Litopenaeus stylirostris by studying salinity tolerance and osmoregulatory capacity. Shrimp at different larval and postlarval stages were exposed to various salinities and survival was monitored for $24 \mathrm{~h}$. Survival rates exceeded $80 \%$ at salinity over $25 \mathrm{ppt}\left(750 \mathrm{mOsm} \cdot \mathrm{kg}^{-1}\right)$ at all the stages. At salinities below to $25 \mathrm{ppt}$, salinity tolerance was higher in nauplii and zoeae than in mysis larvae. Postlarval stages were able to withstand lower salinities, e.g. $6.0 \mathrm{ppt}\left(176 \mathrm{mOsm} \cdot \mathrm{kg}^{-1}\right)$ at PL9 stage, but they were more sensitive than larvae to salinities over $35 \mathrm{ppt}\left(1035 \mathrm{mOsm} \cdot \mathrm{kg}^{-1}\right)$. Zoea and mysis larvae slightly hyper-regulated at all tested salinities. After metamorphosis, postlarvae progressively acquired the adult pattern of hyper-hypo-osmoregulation: At PL9, the estimated isosmotic salinity was $24.5 \mathrm{ppt}\left(720 \mathrm{mOsm} \cdot \mathrm{kg}^{-1}\right)$; below and over this salinity, animals hyper-regulated and hypo-regulated, respectively. Finally, we determine the effects of lowering salinity at different animal development stages. We conclude that seawater salinity (35 ppt) is optimum during larval stages; but for postlarval stages, lowering salinity at $27 \mathrm{ppt}$ leads to a better growth in 19 days compared to those maintained at $35 \mathrm{ppt}(1.07 \mathrm{mg} \mathrm{vs} 0.47 \mathrm{mg})$. These results are in agreement with penaeid natural life cycle during which larvae are released in oceanic water while juveniles live in coastal areas where salinity is more fluctuant.
\end{abstract}

\section{Highlights}

Osmoregulation capacity in L. stylirostris is weak in the early life stage. Postlarvae progressively acquired the adult pattern of hyper-hypo-osmoregulation. At PL9, the estimated isosmotic salinity was $24.5 \mathrm{ppt}\left(720 \mathrm{mOsm} \cdot \mathrm{kg}^{-1}\right)$. A A two-fold-growth in 19 days-old postlarvae was obtained in dilute seawater compared to seawater conditions.

Keywords: Penaeid ; Litopenaeus stylirostris ; Ontogeny ; Osmoregulation ; Growth 


\section{Introduction}

Shrimp farming in New Caledonia is based upon the blue shrimp species, Litopenaeus stylirostris, which was imported for the first time in 1970's from Latin America (AQUACOP, 1979). The successful adaptation of the blue shrimp to local conditions and zootechnical improvements have permitted to rear the broodstock in captivity and to reach a production of 2500 metric tons of shrimps in 2005 , which was equivalent to $57 \%$ of L. stylirostris world production (FAO, 2012). However, a $50 \%$ decline of the caledonian shrimp production has been recorded since 2009. This loss can be partly attributed to difficulties in producing juveniles in hatcheries, particularly to obtain nauplius during the warm season and unexplained mortalities at different larval rearing periods. At the same time, salinity water in the hatcheries can fluctuate from 20 to 40 ppt depending on the season. Today, a better understanding of key physiological functions of $L$. stylirostris may lead to improvements in technical management to sustain the production of juvenile blue shrimp in New Caledonia.

The ecology of penaeid shrimps has been widely described in the literature (Dakin, 1938; Linder and Anderson, 1954; Fujinaga, 1955; Dall et al., 1990; Bailey-Brock and Moss, 1992). Penaeid juveniles commonly inhabit estuaries with fluctuating environmental conditions while adults of these species migrate in oceanic deep water to spawn. After hatching, Litopenaeus stylirostris goes through different larval stages (Kitani, 1985): 6 nauplii, 3 zoeae and 3 mysis stages that live in a stable marine environment. But after the metamorphosis, postlarvae settle close to the coast in estuarine waters (Garcia and Le Restre, 1981). Temperature and salinity are among the abiotic factors that fluctuate in these shallow environments (Kinne, 1963; Kinne, 1964). For penaeid species like $P$. merguiensis, the influence of salinity can have a greater impact on survival than temperature in the early stages (Zacharia and Kakati, 2004).

Osmoregulatory mechanisms allow the adaptation of aquatic animals to salinity changes. But the capacity to osmoregulate differs among crustaceans and Charmantier (1998) has described three patterns of ontogeny of osmoregulation. A first group of species, generally marine and stenohaline, are osmoconformers all their lifetime: Chionoecetes opilio (Kalber, 1970), Libilia emarginata (Kalber, 1970), Palunirus species (Dall, 1974; Lucu et al., 2000) or Hepatus ephiliticus (Charmantier and Charmantier-Daures, 1995). A second group of animals, mostly euryhaline, have a strong ability to osmoregulate in their early life stages and a wide tolerance to salinity variations; mostly euryhaline, this pattern includes Cladocera species (Aladin and Potts, 1995), Gammarus duebeni (Morritt and Spicer, 1995) or Macrobrachium petersi (Read, 1984); in the third pattern, the capacity to osmoregulate shifts from weak to strong during the ontogeny. Several penaeid crustaceans belong to this last group including the penaeid shrimp Peaneus japonicus (Charmantier, 1986; Charmantier et al., 1988) and the osmoregulatory capabilities of this species during ontogenesis is known. Investigations in L. stylirostris have shown that juveniles and adults are hyper-hypoosmoregulators (Lemaire et al., 2002; Wabete et al., 2006), but no studies were conducted to assess osmoregulation capacities during $L$. stylirostris larval and postlarval developments.

The aim of this study was to investigate the variations in salinity tolerance during the postembryonic development of $L$. stylirostris, to establish the relationship with the changes in the pattern of osmoregulation and to investigate the potential improvements in zootechnical parameters resulting from an adjustement of the larval rearing salinity. 


\section{Material and methods}

\subsection{Animals}

Larvae and juveniles of the blue shrimp (Litopenaeus stylirostris) were supplied by the LEAD hatchery (Ifremer New Caledonia) from June 2009 to May 2010. Breeders were reared during 8 months in earthen ponds, and then transferred into the hatchery. In order to stimulate spawning, water temperature of $29^{\circ} \mathrm{C}$, a $14: 10 \mathrm{hrs}$ day:night photoperiod and an enriched diet were used. Eyestalk ablation was also practiced on the females and they were artificially inseminated. Nauplii collected on the same day were stocked in a 2 cubic meter tank and mass reared according to Ifremer protocol (Pham, unpublished) : density of 180 larvae per liter, salinity of $35 \mathrm{ppt}$, temperature of $29^{\circ} \mathrm{C}$ and $14: 10 \mathrm{hrs}$ day:night photoperiod. Microparticles and Artemia nauplii were given ad libitum. Larvae were treated with antibiotics (2 ppm of erythromicyn) at day 3, 5, 7 and 9 without water renewal. After this period, $50 \%$ to $100 \%$ of the water was changed every day. Animals were kept in the hatchery for 10 days after becoming postlarvae. Rostral formulae (RF) was used to determine the postlarval stage: for instance, a RF of [3-0] meant that the numbers of spines over and under the rostrum were 3 and 0 , respectively; postlarvae were designated with reference to the stage order (PL1, PL2, etc...) or to the number of days following metamorphosis ( $\mathrm{P} 1, \mathrm{P} 2$, etc...). Correspondences between the postlarval stage, the number of days after metamorphosis and the rostral formulae are given in Table 1 (Goarant et al., 1998; Pham, unpublished data).

\subsection{Preparation of media}

Tests to salinity exposure are commonly used to evaluate the shrimp larval quality predicting further performances of growth and fitness in grow out ponds (AQUACOP et al., 1991; Tackaert et al., 1989; Samocha et al., 1998; reviewed by Palacios and Racotta, 2007). Media at different salinities were prepared from $5 \mu \mathrm{m}$-sterilized seawater by adding sterilized and demineralized freshwater or marine salt (Sera, Germany). The media were prepared and stored over one week at most in a dark room at $24{ }^{\circ} \mathrm{C}$. Each medium was checked with an osmometer (WESCOR Vapro 5520, USA) for osmolality expressed in mOsm. $\mathrm{kg}^{-1}$. Osmolality standard solutions of 290 and $1000 \mathrm{mOsm} \cdot \mathrm{kg}^{-1}$ (WESCOR, USA) were used to calibrate the osmometer. Conversion in salinity was done with $1 \mathrm{ppt}$ equivalent to $29.41 \mathrm{mOsm} . \mathrm{kg}^{-1}$. Different salinities were tested depending on the larval stages: at nauplius $(10 ; 14 ; 19 ; 22$; $24 ; 27 ; 31 ; 36.5 ; 42 ; 46$ ppt); at zoea 2 (19; 20; 22; 25; 26; 31; 33; 36.5; 42; 46 ppt); at mysis 2 (19; 20; 22; 25; 30; 36.5; $42 ; 46$ ppt); at PL1 (17; 18,5; 19; 22; 24; 25.5; 30.5; 35; $42 ; 46$ ppt); at PL4 (14; 16; 18; 21; 26; 30.5; 36.5; 42; 46 ppt); at PL9 $(0 ; 5 ; 6 ; 12 ; 18 ; 25 ; 30.5 ; 38$; $41 ; 46 \mathrm{ppt})$.

\subsection{Salinity tolerance}

Animals were collected at the same time from larval rearing tanks at different stages: nauplii, zoea 2, mysis 2, PL1 (P2), PL4 (P8) and PL9 (P25). Eight to ten salinities were tested at each stage in three replicates: ten animals were transferred directly in $30 \mathrm{ml}$ conical centrifuge tubes containing the experimental media. For PL9 stage, only 5 animals were placed in $100 \mathrm{ml}$ containers in 6 replicates. Control animals were kept in seawater salinities (35 to $38 \mathrm{ppt}$ ). All the containers were kept in a thermoregulated chamber at larval rearing temperature $\left(29^{\circ} \mathrm{C}\right)$. No food was given during the experiment.

Dead animals were counted every hour during the first $6 \mathrm{hrs}$ and then at $24 \mathrm{hrs}$ after immersion. Animals were considered as dead when no heartbeat and lack of movement after stimulation were observed. Lethal salinities for $50 \%$ of animals at 6 hrs (6 h LS50) and at 24 hrs (24 h LS50) were estimated. 
Statistical comparisons were performed between survival rate at each stage according to salinity at $6 \mathrm{hrs}$ and $24 \mathrm{hrs}$ separately. One-way analysis of variance was used to detect the differences in survival rates after data $\arcsin (\sqrt{ })$ transformation with Statview sofware. Student's $t$-tests were used to resolve differences among treatment means with $\alpha=0.05$.

\subsection{Osmoregulation}

In order to determine the hemolymph osmolality at different stages and different salinities, the animals were stocked in the same way as in the tolerance test. Five to six salinities (from 6 to $45 \mathrm{ppt}$ ) were used for larvae and postlarvae at $29^{\circ} \mathrm{C}$.

A minimum adaptation time of $4 \mathrm{hrs}$ was allowed after direct transfer of the animals into the considered salinity prior to the measurements of hemolymph osmolality. Before sampling hemolymph, animals were dried with filter paper and immersed into mineral oil to avoid evaporation. Hemolymph was obtained by inserting a micropipette into the animal heart. Hemolymph osmotic pressure was obtained by measuring the freezing point depression with a nanoliter osmometer (Otago osmometers, New Zealand) requiring 10 to 30 nanoliter of sample. Measurements were conducted at least on three animals for each salinity and each stage.

For each stage and salinity tested, the osmoregulatory capacity (OC), defined as the difference between the hemolymph osmolality and the medium osmolality, was calculated.

\subsection{Larval and postlarval rearing experiments}

Four successive experiments were conducted to determine salinity impact on larval and postlarval rearing. Nauplius (Nii) hatched on the same day were gathered together in a tenliter bucket and the number of larvae was estimated with five samples of one ml. Each tank of 80 to 150 liters was stocked at a density of 167 to180 nauplii per liter. The larval rearing was conducted as described above. Temperature, salinity, survival and growth were controlled every day. Survival was estimated by counting the number of larvae in $100 \mathrm{ml}$ in three to five replicates. From Nii to PL1, a development index (DI) was calculated by using the stage index according to Villegas and Kanazawa (1980); a rank was attributed to each larval stage (0 to Nii, 1 to Zoea 1 ...till 7 to PL1) weighted by the percentage of animal at each stage in a day. After PL1, growth was estimated with the percentage of each rostral formula in a $30 \mathrm{PL}$ sample and/or the individual mean dry weight in 100 individuals for each replicate. A preliminary experiment was done to test the effect of a direct transfer from seawater to six salinities $(20,25,28,31,35$ and 39 ppt with no replicate) during the larval phase, from nauplius to mysis for 8 days.

The second trial was conducted during 15 days to determine if postlarval survival can be affected by salinity variation during larval phase. The experiment started at nauplius stage with the three salinities which have obtained the best results in the first experiment $(28,30$ and $35 \mathrm{ppt}$ ); these salinities tested in duplicates were maintained until day 9 and then, a $50 \%$ renewal water was operated at D9, D11, D13 and D14 with seawater (35 ppt) till PL3-4.

The third and fourth experiments were assessed to test the effect of different salinities in postlarval period. The third one started with two salinities (30 and $35 \mathrm{ppt}$ ) in twelve replicates from D0 (Nii) to D9 (mysis-PL). Due to high mortality in tanks at $30 \mathrm{ppt}$, only $35 \mathrm{ppt}$ treatment was kept after D9 and the twelve tanks were shared in four groups with renewal water at different salinities in triplicates between D9 and D20: 24 (treatment 35-24), 27 (treatment 3527), 30 (treatment 35-30) or 35 ppt (control treatment). 
The fourth experiment was conducted for a whole larval rearing period (32 days). From D0 to D9, 6 tanks were filled with seawater at 35 ppt. At D9, the salinity of 3 of the tanks was gradually lowered to $27 \mathrm{ppt}$ (treatment 35-27) while the 3 other tanks were maintained at 35 ppt (treatment 35-35). At D19, the animals of each tank were harvested and transferred to another tank for 12 more days at a lower density of $20 \mathrm{PL} /$ liter. The PL from treatment 35-35 were divided up for the last period of the experiment to 3 tanks at a salinity of $27 \mathrm{ppt}$ (treatment 35-35-27) and 3 at 35 ppt (treatment 35-35-35). The PL from treatment 27-27 were also transferred but salinity was maintained at $27 \mathrm{ppt}$ (treatment $27-27-27$ ).

Statistical comparisons were performed by using oneway analysis of variance to detect the differences in survival rates after data $\arcsin (\sqrt{ })$ transformation and by non parametric analysis of variance (Kruskal-Wallis ANOVA) for osmoregulatory capacity with XLS Stat 2011 sofware. Probability limit of $p \leq 0.05$ was considered as significant.

\section{Results}

\subsection{Salinity tolerance}

Salinity tolerance varied according to development stages (Fig.1). Nauplii survival was higher than $80 \%$ for salinities $>26.7$ ppt $\left(785\right.$ mOsm.kg $\left.{ }^{-1}\right)$ after 6 and 24 hrs. At 19.3 ppt (569 mOsm. $\mathrm{kg}^{-1}$ ), significant mortality was observed after $6 \mathrm{hrs}$ and only $30 \%$ survived after $24 \mathrm{hrs}$ (Fig. 1A). At 42 and $46 \mathrm{ppt}$, no or low mortality was observed at this larval stage but higher activity was noticed in these conditions.

In zoea stage, survival was close to $80 \%$ from 21.8 to $45.7 \mathrm{ppt}\left(641\right.$ to $\left.1345 \mathrm{mOsm} . \mathrm{kg}^{-1}\right)$ after $24 \mathrm{hrs}$. But at $20.2 \mathrm{ppt}\left(595 \mathrm{mOsm} \cdot \mathrm{kg}^{-1}\right)$, only $13 \%$ of the zoea 3 were alive at $6 \mathrm{hrs}$ and all were dead at $24 \mathrm{hrs}$ (Fig. 1B). Significant mortalities were also observed at salinities above $42 \mathrm{ppt}$ with a loss between 30 and $40 \%$ after $24 \mathrm{hrs}$. Salinity tolerance in zoea 2 was similar to zoea 3 (not illustrated).

In mysis 2, survival rate exceeded $80 \%$ after $24 \mathrm{hrs}$ at salinities $>26.3 \mathrm{ppt}\left(775 \mathrm{mOsm} . \mathrm{kg}^{-1}\right)$. At 24.5 ppt $\left(723 \mathrm{mOsm} . \mathrm{kg}^{-1}\right)$, survival declined and only $53 \%$ of the specimen were alive after 24 hrs. At $21.8 \mathrm{ppt}\left(641 \mathrm{mOsm} . \mathrm{kg}^{-1}\right)$, all the mysis were dead within 1 hour (Fig. $1 \mathrm{C}$ ). After 24 hours at $46 \mathrm{ppt}$, low but significant mortality was noticed compared to $35 \mathrm{ppt}$.

In PL1 (P2), survival was over $80 \%$ at salinities $>25.5$ ppt $\left(750\right.$ mOsm. $\left.\mathrm{kg}^{-1}\right)$. At $21.6 \mathrm{ppt}(636$ mOsm. $\mathrm{kg}^{-1}$ ), only $10 \%$ and $3 \%$ of animals survived after $6 \mathrm{hrs}$ and $24 \mathrm{hrs}$, respectively. At $17.1 \mathrm{ppt}$ (503 mOsm. kg ${ }^{-1}$ ), total mortality occurred within $1 \mathrm{hr}$ (Fig. 1D). No significant difference in survival rate was observed at salinities above 42 ppt compared to control treatment but a hyperactivity and abnormal behaviour were detected.

At PL4, survival was close to $100 \%$ after 6 hrs from 20.8 to 45.7 ppt (612 and 1345 mOsm. $\left.\mathrm{kg}^{-1}\right)$. This high survival rate was maintained after $24 \mathrm{hrs}$ except at $45.7 \mathrm{ppt}$ (1345 mOsm. $\mathrm{kg}^{-1}$ ) where survival was $63 \%$. Only $43 \%$ of the animals survived at $18.1 \mathrm{ppt}$ (532 mOsm. kg ${ }^{-1}$ ) after $6 \mathrm{hrs}$ and $24 \mathrm{hrs}$ (Fig. 1E). Survival rates were only lower than $60 \%$ after 24 hrs at 46 ppt in PL4.

At PL9, animals could stand osmolarity variations from 6 to $45 \mathrm{ppt}\left(175\right.$ to $1350 \mathrm{mOsm} \cdot \mathrm{kg}^{-1}$ ); $93 \%$ of shrimp were still alive one day after immersion at the lowest salinity. In media more concentrated than seawater, $30 \%$ of mortality was observed after $24 \mathrm{hrs}$ (Fig. 1F). At salinity above $41 \mathrm{ppt}$, low but significant mortality was recorded after $24 \mathrm{hrs}$ and even after $6 \mathrm{hrs}$ for the PL9. In all cases, animals showed abnormal behaviour, particularly hyperactivity. 
Values of lethal salinities (LS50) at 24 hrs are given in Fig. 2. LS50 was 22 ppt in nauplii. In zoea stages, the LS50 were 22 and $21 \mathrm{ppt}$. The highest LS50 was recorded in mysis stages with a value of 25 ppt. LS50 were 23 ppt, 19 ppt 17 ppt and 3 ppt in PL1, PL2, PL4 and PL9, respectively.

\subsection{Osmoregulation}

Variations of hemolymph osmolality vs external osmolality and salinity are illustrated in Fig. $3 \mathrm{~A}$; the corresponding osmoregulatory capacities $(\mathrm{OC})$ are given in Fig. 3B.

Larvae, zoeae and mysis slightly hyper-osmoregulated over the range of tolerable salinities from 668 to 1347 mOsm. $\mathrm{kg}^{-1}$ (Fig. 3A). OCs ranged from 0 to $150 \mathrm{mOsm} \cdot \mathrm{kg}^{-1}$. The OC values were significantly lower at high salinities in mysis stages. A progressive change in pattern of osmoregulation was observed following metamorphosis, in postlarvae. PL1 slighty hyper-hypo-osmoregulated. Hyper-OCs were below $50 \mathrm{mOsm} \cdot \mathrm{kg}^{-1}$, with hypo-OCs ranging from -10 to -100 mOsm. kg ${ }^{-1}$ (Fig. 3B). At $971 \mathrm{mOsm} \cdot \mathrm{kg}^{-1}$, OC was close to zero. The capacity to hyper- and hypo-osmoregulate increased slightly in PL4 (hyper-OC, 50-100 mOsm. $\mathrm{kg}^{-1}$; hypo-OC, -100 to -200 mOsm. $\mathrm{kg}^{-1}$ ) with a shift between 680 and $851 \mathrm{mOsm} \cdot \mathrm{kg}^{-1}$. In PL9, the OC was amplified; at this stage, hyper-OC was $200 \mathrm{mOsm} \cdot \mathrm{kg}^{-1}$ and up to $380 \mathrm{mOsm} \cdot \mathrm{kg}^{-1}$ at the lowest salinity (6 ppt) where no mortality was observed. A similar trend was noted for hypo-OC that reached $-580 \mathrm{mOsm} \cdot \mathrm{kg}^{-1}$ at the highest tested salinity of $46 \mathrm{ppt}$. All the OC were significantly different at this stage except at 363 and $530 \mathrm{mOsm} \cdot \mathrm{kg}^{-1}$. The isosmotic point was determined from the intersection between the isosmotic line and the osmoregulation curve in postlarval stages, and it was $720 \mathrm{mOsm} \cdot \mathrm{kg}^{-1}$ (24.5 ppt) at PL9 (Fig. $3 A)$.

\subsection{Larval and postlarval rearing experiments}

In the first experiment (Fig. 4), survival rates in nauplius stages were above $80 \%$ at 20 and $25 \mathrm{ppt}$ only the first day. Then they quickly decreased and at D3, total mortality was observed at these two lowest salinities. At salinities of $28 \mathrm{ppt}$ or above, the survival rate was above $70 \%$ at $\mathrm{D} 7$ and $\mathrm{DI}$ around 4 was measured in all media.

In the second experiment (Table 2), larval survival rates at $28 \mathrm{ppt}, 30 \mathrm{ppt}$ and $35 \mathrm{ppt}$ were $56.2 \%, 64.4 \%$ and $80.8 \%$, respectively after 15 days. However, development was better in the lower salinity media with $20 \%$ of PL4 and $80 \%$ PL3 while all the animals were still in PL3 in the other treatments.

In the third experiment (Fig.5), the evolution of the survival rates was similar for the $30 \mathrm{ppt}$ and 35 ppt treatments until D4, i.e. at D3, there were 87 and 90\%, respectively. From D5, survival rate decreased in the 30 ppt treatment and was only $53 \%$ at D7 while it was still above $85 \%$ in the 35 ppt treatment. Growth was significantly lower in dilute seawater $(\mathrm{DI}=2.1 \pm 0.15)$ than in seawater $(\mathrm{DI}=2.8 \pm 0.28)$ only at $\mathrm{D} 3$; this difference was wider but not statistically different at D7 since DI were $3.80 \pm 1.22$ and $5.18 \pm 0.98$ for 30 ppt and 35 ppt, respectively. Mortalities were observed in 10 of the 12 replicates at $30 \mathrm{ppt}$ so, all the tanks of this treatment were eliminated. At D9, water renewal at different salinities was conducted until D19, and the best survival rate (84\%) was obtained in the 35-35 treatment, while the lowest one $(73 \%$ ) was observed for the $35-24$ treatment (table 3 ). Final mean weights were between $0.47 \mathrm{mg}(35-30$ treatment) and $0.60 \mathrm{mg}$ (35-24 treatment) and the percentage of PL4 was above $78 \%$ for all the treatments. No significant difference was observed for any of these parameters among the different treatments $(\alpha=0.05)$.

The fourth experiment (Table 4) started with 6 tanks at 35 ppt until D9. The mean survival rate at D9 was $85 \%$ with a DI of 5 . At D19, 35-27 treatment and control treatment (35-35) 
showed $56.6 \%$ and $47.6 \%$ survival, respectively. The percentage of PL4 and the mean dry weight were also higher in the dilute seawater but the differences were not significant at this stage. In the last period of the experiment, the mean survival rates were respectively $97.2 \%$, $89.4 \%$ and $84.2 \%$ for the $35-27-27,35-35-27$ and 35-35-35 treatments, with no significant difference. On the other hand, significant differences in growth were obtained between the animals maintained at 27 ppt from D9 (35-27-27 treatment) and the 35-35-35 treatment with $1.07 \mathrm{mg}$ and $0.43 \mathrm{mg}$, respectively (Fig. 6). The difference were also significant in development stage between the two treatments with $52 \%$ of PL5 in dilute seawater while only $11 \%$ of PL5 or more was observed in the control group. The 35-35-27 treatment has obtained intermediate results but none of them was significantly different from the two others treatments.

\section{Discussion}

Tests to salinity exposure are commonly used to evaluate the shrimp larval quality predicting further performances of growth and fitness in grow out ponds (AQUACOP et al., 1991; Tackaert et al., 1989; Samocha et al., 1998; Racotta et al., 2003; Palacios and Racotta, 2007). Under the present experimental conditions (starvation for $24 \mathrm{hrs}$ ), a salinity shock is a very stressful test for penaeid at early stages but it permitted to determine the critical periods in the early development of $L$. stylirostris. In this study, tolerance to an acute salinity change varied with the developmental stage, and from nauplius to PL1 the salinity tolerance decreases. An increase of 2 ppt between 17 and 25 ppt was applied to detect the differences of sensitivity among the stages. The LS50 at $24 \mathrm{hrs}$ in nauplii, zoeae, mysis and PL1 were 23 ppt, $22 \mathrm{ppt}, 25 \mathrm{ppt}$ and $23 \mathrm{ppt}$, respectively. In other decapod crustaceans as Armases miersii (Anger, 1996), P. japonicus (Charmantier et al., 1988), Carcinus maenas (Cieluch et al., 2004) or Cangron cangron (Cieluch et al., 2005), a lower salinity tolerance was also reported for stages close to metamorphosis. The lower salinity tolerance of mysis compared with nauplius or zoea stages could be explained by a higher energy expenditure with the shift from a herbivorous feeding regime to a carnivorous one, some anatomical changes and the occurrence of incomplete osmoregulatory functions as we observed. A nutritional hypothesis could also explain a higher resistance in nauplius compared to others larval stages. During the early development, a larva has important energy requirements supplied by the yolk at nauplius stage; but in zoea and mysis stages, food supply is necessary and starvation for 24 hrs could be an additional stress.

In postlarvae older than PL1, tolerance to lower salinity range was observed while resistance to high salinity slightly decreased. A study of the salinity preference of four Penaeus species -including $L$. stylirostris has shown that postlarvae were more attracted by low salinity waters (Mair, 1980). Juveniles of some Penaeus species were found to tolerate lower salinities than adults (Dall, 1981). An improvement in salinity tolerance throughout postlarval development from 2 day-old postlarvae (5\% of survival after $2 \mathrm{hrs}$ at $20 \mathrm{ppt}$ ) to 20 day-old postlarvae of Litopenaeus vannamei (90\% of survival after $2 \mathrm{hrs}$ at $0 \mathrm{ppt}$ ) has also been reported by Aquacop et al. (1991).

Similar data on the ontogeny of osmoregulation in young stages are also available in another penaeid species $P$. japonicus (Charmantier et al., 1988). In this species, mysis were also found to be the most sensitive stages to salinity variations, and hyper-hypo-osmoregulation was gradually established after metamorphosis. Through transmission electronic microscopy observations, Bouaricha et al. (1994) have shown that osmoregulatory organs were progressively implicated in ionic regulation during postembryonic development of this species: the branchiostegites and pleurae at zoea 2 then, the epipodites in postlarval stages. 
L. stylirostris is a slight hyper-osmoregulator close to osmoconformity in the larval stages at any tested salinity. After metamorphosis, the osmoregulation pattern changes progressively towards hyper-hypo-osmoregulation. Compared to previous results in adults (Wabete et al., 2006), this change is achieved at PL9 (25 day old postlarvae at $\left.29^{\circ} \mathrm{C}\right)$. At salinities ranging from 6 to 45 ppt, PL9 can maintain the hemolymph osmolality values between 550 and 800 mOsm. kg ${ }^{-1}$ and the isosmotic point is 720 mOsm. $\mathrm{kg}^{-1}$. These values are slightly lower than those obtained in the same species by Lemaire et al. (2002) and Wabete et al. (2006) on 10 $\mathrm{g}$ subadults at $28^{\circ} \mathrm{C}$ and $40 \mathrm{~g}$ adults at $26.7^{\circ} \mathrm{C}$ with an isosmotic point at $735 \mathrm{mOsm} . \mathrm{kg}^{-1}$ and $756 \mathrm{mOsm} . \mathrm{kg}^{-1}$, respectively. However, these results are in agreement with the previously observed increase of haemolymph osmotic pressure with the body weight in the same species (Lignot et al., 1999b). Isosmotic points were evaluated in Palaemon pacificus, Exopalaemon orientalis, Metapenaeus joyneri and Penaeus semisulcatus with values of 648, 653,649 and $412 \mathrm{mOsm} . \mathrm{kg}^{-1}$ respectively (Dissanayake and Ishimatsu, 2011) at $22^{\circ} \mathrm{C}$. And the authors have also shown that the two penaeids were less tolerant to low salinity of $10 \mathrm{ppt}$ after 2 days compared with the two palaemonids. With a higher isosmotic point than the previous species, the blue shrimp juveniles were able to tolerate $5 \mathrm{ppt}$ for one day in our experiment. In other trials, it was noticed that the same species juveniles could stand salinity as low as 3 ppt for 5 days (Pham, not published) at the optimum temperature of $28^{\circ} \mathrm{C}$.

L. stylirostris may be associated to the third pattern of osmoregulation capacity as defined by Charmantier (1998). In this group, the early postembryonic stages are osmoconformers or they slighty osmoregulate, Thereafter, a shift occurs at the metamorphic larva-juvenile transition and the animals become progressively hyper-hypo-osmoregulators as the adults do. Studies conducted on other decapods have revealed similar ontogeny of osmoregulation in Homarus americanus (Charmantier et al., 1984; 1988; 2009), Penaeus japonicus (Charmantier, 1986; Charmantier et al., 1988), Homarus gammarus (Thuet et al., 1988), Cancer irroratus (Charmantier and Charmantier-Daures, 1991), Carcinus maenas (Cieluch et al., 2004) and Crangon crangon (Cieluch et al., 2005), despite different types of habitat or migration. However, in the crab C. maenas, osmocomforming zoea stages can tolerate salinity as low as 15ppt; this ability may be an ecological adaptation as the eggs hatch in the same habitat as the one occupied by adults and characterized by low and fluctuant salinities (Cieluch et al., 2004). In penaeid shrimps, adults migrate to oceanic water to spawn, where salinity conditions are stable and low salinity tolerance is not necessary. After metamorphosis, the progressive shift to a juvenile/adult type of osmoregulation allows the postlarvae to enter estuaries where salinity is more variable than in open sea.

In conditions close to larval rearing productions, $L$. stylirostris larvae have shown best survival rates and reliable results at salinities of $35 \mathrm{ppt}$ compared to lower salinity media. In the same species, Marty-Ordonez (1972) has shown that breeders had a preference for high salinities around 35-38 ppt and best survival rates at first postlarval stage were also obtained at seawater salinity. In a review on penaeid biology, Rothlisberg (1999) concluded that oceanic salinities were necessary to obtain good growth and survival of $P$. merguiensis. This result was confirmed by Zacharia and Kakati (2004) who observed that a salinity range of 30$35 \mathrm{ppt}$ was optimum for larval development of this species. Several works about other penaeid species such as $P$. kerathurus (Klaoudatos, 1978), P. plebejus, M. macleayi (Preston, 1985), $M$. ensis (Chu and So, 1987), $P$. penicillatus, $M$. affinis, $P$. monodon (Parado-Estepa et al., 1993) or P. stylifera (Nisa and Ahmed, 2000) have confirmed that a salinity above 30 ppt was the best for larval development. This disability to tolerate dilute seawater before metamorphosis is linked to the osmoconformity of the regulation pattern at this development stage and which can upset nutritional processes. For instance, larvae of different crab species exposed to salinity reduction have shown lower food assimilation; moreover, biochemical composition of the osmoconformer Cancer paragus was subject to higher variations than the hyper-regulator $C$. granulata when they were transferred in dilute seawater (Torres et al., 2002). 
On the other hand, larval rearing in dilute seawater after PL1 has shown consistent improvement in growth compared to animals maintained at 35 ppt during all the postembryonic development. Without reaching the isosmotic point estimated at $24-25 \mathrm{ppt}$, a twofold growth was obtained only by decreasing salinity at $27 \mathrm{ppt}$ from the $9^{\text {th }}$ day of larval rearing. These results are in agreement with those observed in Fenneropenaeus paulensis with a better growth at 25 ppt compared to 34 ppt (Lemos et al., 2001). In contrast with larval stages, the same authors suggested a lower food assimilation after metamorphosis in seawater salinity to explain the growth reduction as well as an increase in metabolic demand which would result in lipid catabolism. For other species such as $L$. vannamei, $P$. setiferus, or $P$. schmitti, a lower salinity, between 15 and $25 \mathrm{ppt}$, also seems to be optimal for their growth (Castille and Lawrence, 1981; Boyd, 1989). And Dall (1981) even noticed that juveniles of some Penaeus species were found to tolerate lower salinities than adults.

With temperature, salinity is the most important environmental factor which affect the aquatic species metabolic rate. Animals reared in salinity conditions close to their isosmotic point can take advantage of the situation by saving energy, devoted to ionic regulation, for growth. Oxygen consumption and ammonia excretion are often used as indicators to estimate the energy metabolism in crustaceans and Zang et al. (2009) have shown that in L. vannamei juveniles, their values were lower at 5 ppt compared with 25 ppt while $\mathrm{O} / \mathrm{N}$ ratio was higher. On the other hand, in the adult chinese mitten crab Eriocheir sinensis, oxygen consumption increases but the ammonia excretion decreases with salinity and the food consumption is not affected by salinity (Normant et al., 2012). This difference of effect on bioenergetic parameters can be explained by higher tolerance to salinity variation in the brachyuran crabs compared to penaeids. Optimum and adaptation to salinity conditions depend on both species and considered developmental stage.

\section{Conclusion}

By optimizing media salinity, shrimp can stand up to a greater variation of other abiotic factors such as temperature (Kumlu et al., 2000, Zacharia and Kakati, 2004) or oxygen concentration (Rosa et al., 1997). Based on the results presented here in larval rearing of $L$. stylirostris in New Caledonia, it is now recommended to maintain seawater salinity from nauplius to PL1 and then, to progressively lower salinity by renewing with desalted water. These results and the subsequent procedures are in accordance with the biological cycle of penaeids in their natural environment. Spawning occurs in offshore seawater where larvae are not exposed to salinity variations. The time for juveniles to reach the coastal and estuarine zones depends on several external parameters such as oceanic circulation, light or temperature, but also on intrinsic factors such as growth rate or behavior of larvae (CalderonAguilera et al., 2003). Before reaching the coastal nursery areas, shrimps must have acquired a high capacity to osmoregulate to withstand salinity variations.

\section{Acknowledgements}

This research was financially supported by North and South Provinces of New Caledonia. The authors would like to thank A.-L. Marteau for her help in supplying L. stylirostris larvae and $\mathrm{T}$. Laugier for valuable comments on this article. 


\section{References}

Aladin, N.V., Potts, W.T.W., 1995. Osmoregulation capacity of the Cladocera. J. Comp. Physiol. B, 164, 671-683.

Anger, K.,1996. Salinity tolerance of the larvae and first juveniles of a semiterrestrial grapsid crab, Armases miersii (Rathbun). J. Exp. Mar. Biol. Ecol. 202, 205-223.

Anger, K., Charmantier, G., 2000. Ontogeny of osmoregulation and salinity tolerance in a mangrove crab, Sesarma curacaoense (Decapoda, Grapsidae). J. Exp. Mar. Biol. Ecol., 251, 265-274.

AQUACOP, 1979. Proceedings of the Tenth Annual Meeting of World Mariculture Society. Penaeid reared broodstock: closing the cycle of $P$. monodon, $P$. stylirostris and $P$. vannamei. Proc. $10^{\text {th }}$ annual Meeting of the World Aquaculture Society, 10, pp. 445-452.

AQUACOP, Le Moullac, G., Damez D., 1991. Modélisation de la résistance aux chocs de salinité des postlarves de Penaeus vannamei. Aquat. Liv. Ressour. 4, 169-173.

Bailey-Brock, J.H., Moss, S.M. ,1992. Penaeid taxonomy, biology and zoogeography. In: Fast A.W. and Lester L.J. (Eds). Marine shrimp culture: principles and practices. Developments in aquaculture and fisheries science, Vol. 23. Elsevier Science Publisher B.V., The Netherlands. pp. 9-27.

Bouaricha, N., Charmantier-Daures, M., Thuet, P., Trilles, J.-P.,Charmantier, G., 1994. Ontogeny of osmoregulatory structures in the shrimp Penaeus japonicus (Crustacea, Decapoda). Biol. Bull. 186 (1), 29-40.

Boyd, C.E., 1989. Water quality management and aeration in shrimp farming. Fisheries and Allied Aquaculture Departmental Series No. 2. Auburn University Press, 70 pp.

Calderon-Aguilera, L.E., Marinonea, S.G., Aragon-Noriega, E.A., 2003. Influence of oceanographic processes on the early life stages of the blue shrimp (Litopenaeus stylirostris) in the Upper Gulf of California. J. Mar. Syst. 39, 117-128.

Castille, F.L., Lawrence, A.L., 1981. A comparison of the osmotic, sodium and chloride concentrations between the urine and hemolymph of Penaeus setiferus ( $L$ ) and Penaeus stylirostris Stimpson. Comp. Biochem. Physiol. 70A: 525-528.

Charmantier, G., 1986. Variation des capacités osmoregulatrices au cours du développement post-embryonnaire de Peaneus japonicus Bate, 1888 (Crustacea, Decapoda). C.R. Acad. Sci. Paris, 303, pp. 217-222.

Charmantier G., 1998. Ontogeny of osmoregulation in crustaceans: a review. Invert. Reprod. Develop. 33, pp.177-190.

Charmantier, G., Charmantier-Daures, M., Aiken, D. E., 1984. Variation des capacités osmorégulatrices des larves et post-larves de Homarus americanus $\mathrm{H}$. Milne-Edwards, 1837 (Crustacea, Decapoda). C.R. Acad. Sci. Paris 299, pp. 836-866.

Charmantier, G., Charmantier-Daures, M., Bouaricha, N., Thuet, P., Aiken D. E., Trilles, J.P., 1988. Ontogeny of osmoregulation and salinity tolerance in two decapod crustaceans: Homarus americanus and Penaeus japonicus. Biol. Bull. 175, No. 1, pp.102-110. 
Charmantier, G., Charmantier-Daures, M., 1991. Ontogeny of osmoregulation and salinity tolerance in Cancer irroratus. Elements of comparison with C. boralis (Crustacea, Decapoda). The Biological Bulletin, 18: 125-134.

Charmantier, G., Charmantier-Daures, M., 1995. Osmoregulation and salinity tolerance in zoeae and juveniles of the snow crab Chionoecetes opilio. Aquat. Liv. Resour. 8, 171-179.

Charmantier, G., Charmantier-Daures, M., Towle, D., 2009. Osmotic and ionic regulation in aquatic arthropods. In "Osmotic and ionic regulation. Cells and animals", D. H. Evans, Ed., CRC Press, NewYork, NY, Oxford, UK, pp. 165-230.

Chu, K.H., So, B.S.H., 1987. Changes in salinity tolerance during larval development of the shrimp Metapeneaus ensis (De Haan). As. Mar. Biol. 4, 41-48.

Cieluch U., Anger, K., Aujoulat, F., Buchholz, F., Charmantier-Daures M., Charmantier G., 2004. Ontogeny of osmoregulatory structures and functions in the green crab Carcinus maenas (Crustacea, Decapoda). J. Exp. Biol. 207, pp. 325-336.

Cieluch U., Charmantier G., Grousset E., Charmantier-Daures M., 2005. Osmoregulation, Immunolocalization of $\mathrm{Na}^{+} / \mathrm{K}^{+}$-ATPase, and ultrastructure of branchial epithelia in the developing Brown Shrimp, Crangon crangon (Decapoda, Caridea). Physiol. Biochem. Zoo. 78(6), pp. 1017-1025.

Dakin, W. J., 1938. The habits and life -history of a penaeid prawn (Peanaeus plebejus Hesse). Proc. Zool. Soc. Lond., Vol. A 108, pp.163-183.

Dall, W., 1974. Osmotic and ionic regulation in the Western rock lobster Panulirus longipes (Milne-Edwards). J. Exp. Mar. Biol. Ecol. 15, 97-125.

Dall, W., 1981. Osmoregulatory ability and juvenile habitat preference in some penaeid prawns. J. Exp. Mar. Biol. Ecol. 54, 55-64.

Dall, W., Hill, B. J., Rothlisberg, P. C., Staples, D. J., 1990. The biology of the Panaeidae. Advances in Marine Biology. Academic Press, London, 27, pp.1-489.

Dissanayake, A., Ishimatsu, A., 2011. Osmoregulatory ability and salinity tolerance in several decapod crustaceans (Paleomonidae \& Penaeidae) of the East China Sea. Plankton Benthos Res. 6(3):135-140.

FAO, 2012. Global capture production 1950-2010. http://www.fao.org/fishery/statistics/globalcapture-production/query/en.

Fujinaga, M., 1955. Life history of Peaneus japonicus. International technical conference on the conservation of the living resources of the sea, April/May 1955, U.N., New-York, pp. 8991.

Garcia, S., Le Restre, L., 1981. Life cycles, dynamics, exploitation and management of coastal penaeid shrimp stocks. FAO Fisheries Technical Paper 203, pp.1-215.

Goarant C., Regnier F., Brizard R., Marteau A.-L., 1998. Acquisition of susceptibility to Vibrio penaeicida in Penaeus stylirostris postlarvae and juveniles. Aquaculture 169, 291-296.

Kalber, F.A., 1970. Osmoregulation in decapod larvae as a consideration in culture techniques. Helgol. Wiss. Meeresunters $n^{\circ} 20,697-706$. 
Kinne, O., 1963. The effects of temperature and salinity on marine and brackish water animals: I. Temperature. Oceanogr. Mar. Bio. Annu. Rev. 1, pp. 301-340.

Kinne, O., 1964. The effects of temperature and salinity on marine and brackish water animals: II. Salinity and Temperature-salinity combinations. Oceanogr. Mar. Bio. Annu. Rev. 2, pp. 281-339.

Kitani H., 1985. Larval development of the blue shrimp Penaeus stylirostris Stimpson reared in the laboratory. Bull. Jpn. Soc. Sci. Fish. 52 (7), pp. 1121-1130.

Klaoudatos, S., 1978. Breeding of Penaeus kerathurus in the laboratory as a proposition to culture them on a commercial scale. Thalassographica 2 (1): 99- 113.

Kumlu, M., Eroldogan, O.T., Aktas, M., 2000. Effects of temperature and salinity on larval growth, survival and development of Penaeus semisulcatus. Aquaculture, 188, 167-173.

Lemaire, P., Bernard, E., Martinez-Paz, J.A., Chim, L., 2002. Combined effect of temperature and salinity on osmoregulation of juvenile and subadult Penaeus stylirostris. Aquaculture 209, 307-317

Lemos, D., Phan, V.N., Alvarez, G., 2001. Growth, oxygen consumption, ammonia-N excretion, biochemical composition and energy content of Farfantepenaeus paulensis PerezFarfante (Crustacea, Decapoda, Penaeidae) early postlarvae in different salinities. J. Exp. Mar. Biol. Ecol. 261, 55-74.

Lignot, J.-H., Cochard, J.-C., Soyez, C., Lemaire, P., Charmantier, G.,1999. Osmoregulatory capacity according to nutritional status, molt stage and body weight in Penaeus stylirostris. Aquaculture 170, 79-92.

Linder, M. J., Anderson, W. W., 1954. Biology of commercial shrimps in Gulf of Mexico: its origin, waters and marine life, edited by P.s. Galtsoff. Bull. Bur. Fish. Wash. 55, No. 89, pp. 457-461.

Lucu, C., Devescovi, M., Skaramuca, B., Kozul, V., 2000. Gill Na ${ }^{+} / \mathrm{K}^{+}$-ATPase in the spiny lobster Palinurus elephas and other marine osmoconformers. Adaptiveness of enzymes from osmoconformity to hyperregulation. Journ. of Exp. Mar. Biol. and Ecol. 246, 163-178.

Mair, J.-McD., 1980. Salinity and water-type preferences of four species of postlarval shrimp (Penaeus) from West Mexico. J. Exp. Mar. Biol. Ecol. 45, 69-82.

Marty-Ordonez, A., 1972. Estudio sobre las preferencias de temperatura y salinidad de $P$. stylirostris en estado adulto. Thesis, Instituto Tecnologico de Estudios Superiores de Monterrey, Escuela de Ciendas Maritimas y Tecnologia de Alimentos, Guaymas, Son, Mexico, $52 \mathrm{pp}$.

Morritt, D. and Spicer, J.I., 1995. Changes in the pattern of osmoregulation in the brackish water amphipod Gammarus duebeni Lilljeborg (Crustacea) during embryonic development. J. exp. Zool. , 273, 271-281.

Nisa, Z., Ahmed, M., 2000. Hatching and larval survival of important penaeid shrimps of Pakistan in different salinities. Pak. J. Zool. 32 (2), 139- 143. 
Normant, M., Krol, M., Jakubowka, M., 2012. Effect of salinity on the physiology and bioenergetics of adult Chinese mitten crabs Eriocheir sinensis. J. Exp. Mar. Biol. Ecol. 416$417 ; 215-220$.

Palacios E., Racotta I. S., 2007. Salinity stress test and its relation to future performance and different physiological responses in shrimp postlarvae Aquaculture 268, 123-135.

Parado-Estepa, F.D., Llobrera, J.A., Villaluz, A., Salde, R., 1993. Survival and metamorphosis of Penaeus monodon larvae at different salinity levels. Israelian Journal of Aquaculture-Bamidgeh 45 (1), 3- 7.

Preston, N., 1985. The effects of temperature and salinity on survival and growth of larval Penaeus plebejus, Metapenaeus macleyi and M. bennettae. In: Rothlisberg, P.C., Hill, B.J., Staples, D.J. (Eds.), Second Australian National Prawn Seminar. NPS2, Cleveland, Australia, pp 31-40.

Racotta, I.S., Palacios, E., Ibarra, A.M., 2003. Shrimp larval quality in relation to broodstock condition. Aquaculture 227, 107-130.

Read, G.H.L., 1984. Intraspecific variation in the osmoregulatory capacity of larval, poslarval, juvenile and adult of Macrobrachium petersi (Hilgendorf). Comp. Biochem. Physiol. 78A, 501506.

Rosa, C., Sanchez, A., Diaz-Iglesia, E., Brito, R., Martinez, E., Soto, L.A., 1997. Critical dissolved oxygen level to Penaeus setiferus and Penaeus schmitti postlarvae ( $\left.\mathrm{PL}_{10-18}\right)$ exposed to salinity changes. Aquaculture, 152, 259-272.

Rothlisberg P.C., 1999. Aspects of penaeid biology and ecology of relevance to aquaculture: a review. Aquaculture 164, 49-65.

Samocha, T. M., Guajardo, H., Lawrence, A. L., Castille, F. L., Speed, M., Mckee, D. A., Page, K. I., 1998. A simple stress test for Penaeus vannamei postlarvae. Aquaculture 165, 233-242.

Tackaert, W., Abelin, P., Dhert, P., Leger, P., Grymonpre, D., Bombeo, R., Sorgeloos, P., 1989. Stress resistance in postlarval penaeid shrimp reared under different feeding procedures. Aquaculture 89 Feb 12, 1989. World Aquaculture Society, Los Angeles, CA, pp. $1-15$

Thuet, P., Charmantier-Daures, M., Charmantier, G., 1988. Relation entre osmoregulation et activités d'ATPase $\mathrm{Na}^{+}-\mathrm{K}^{+}$et d'anhydrase carbonique chez les larves et les postlarves de Homarus gammarus (L.) (Crustacea : Decapoda). J. Exp. Mar. Biol. Ecol., 115: 249-261.

Torres, G., Luis Gimenez, L., Anger, K., 2002. Effects of reduced salinity on the biochemical composition (lipid, protein) of zoea 1 decapod crustacean larvae. J. Exp. Mar. Biol. Ecol. 277, 43-60.

Villegas, C. T., Kanazawa, A., 1980. Rearing of the larval stages of prawn, Penaeus japonicus BATE, using artificial diet. Memoirs of the Kagoshima University Research Center, South Pacific 1: 43-49.

Wabete, N., Chim, L., Pham, D., Lemaire, P., Massabuau, J.-C., 2006. A soft technology to improve survival and reproductive performance of Litopenaeus stylirostris by counterbalancing physiological disturbances associated with handling stress. Aquaculture 260, 181-193. 
Zaccharia, S., Kakati, V. S., 2004. Optimal salinity and temperature for early development stages of Peaneus merguiensis De Man. Aquaculture 232, 373-382.

Zhang, P., Zhang, X., Li, J., Gao, T., 2009. Effect of salinity on survival, growth, oxygen consumption and ammonia- $\mathrm{N}$ excretion of juvenile whiteleg shrimp, Litopenaeus vannamei. Aqua. Res., 40, 1419-1427.

\section{Tables}

Table 1 : Litopenaeus stylirostris. Relation between rostral formulae, postlarval stage and age reared at $29^{\circ} \mathrm{C}$.

\begin{tabular}{lcc}
\hline $\begin{array}{l}\text { Rostral } \\
\text { formulae }\end{array}$ & $\begin{array}{c}\text { Postlarval } \\
\text { stage } \\
\text { Stage number } \\
\text { (PLn) }\end{array}$ & $\begin{array}{c}\text { Age of postlarvae } \\
\text { Number of day after } \\
\text { metamorphosis } \\
\text { (Pn) at 29 }{ }^{\circ} \text { C }\end{array}$ \\
\hline $1 / 0$ & PL1 & P1 to P3 \\
$2 / 0$ & PL2 and PL3 & P4 to P7 \\
$3 / 0$ & PL4 and PL5 & P8 to P12 \\
$4 / 0$ and $4 / 1$ & PL 6 & P13 to P14 \\
$5 / 0,5 / 1$ and $5 / 2$ & PL 7 & P15 to P18 \\
$6 / 0,6 / 1$ and $6 / 2$ & PL 8 & P19 to P22 \\
$7 / 2$ to $9 / 4$ & PL 9 & $>$ P22 \\
\hline
\end{tabular}

Table 2 : Litopenaeus stylirostris. Survival rate and percentage of PL3/PL4 stage according to larval rearing salinity for each replicate.

\begin{tabular}{lcccccc}
\hline Treatment (ppt) & \multicolumn{2}{c}{$\mathbf{2 8}$} & \multicolumn{2}{c}{$\mathbf{3 0}$} & \multicolumn{2}{c}{35} \\
Replicate number & 1 & 2 & 1 & 2 & 1 & 2 \\
\hline Survival rate (\%) & 66.9 & 45.6 & 67.9 & 61 & 85.5 & 76.2 \\
$\%$ [PL3 / PL4] & $80 / 20$ & $80 / 20$ & $100 / 0$ & $100 / 0$ & $100 / 0$ & $100 / 0$ \\
\hline
\end{tabular}


Table 3 : Litopenaeus stylirostris. Survival rate (mean \pm SD), percentage of PL3/PL4 stage and mean dry weight (mean \pm SD) according to postlarval rearing salinity.

\begin{tabular}{lcccc}
\hline Treatment & $35-24$ & $35-27$ & $35-30$ & $35-35$ \\
\hline Number of replicates & 3 & 3 & 3 & 3 \\
Survival rate at D19 (\%) & $73.1 \pm 1.9$ & $77.3 \pm 4.7$ & $79.8 \pm 13.2$ & $84.1 \pm 6.4$ \\
$\%$ PL3 / PL4] & $6 / 94$ & $22 / 78$ & $12 / 88$ & $22 / 78$ \\
\hline Mean dry weight at D19 (mg) & $0.60 \pm 0.03$ & $0.59 \pm 0.04$ & $0.47 \pm 0.21$ & $0.62 \pm 0.07$ \\
\hline
\end{tabular}

Table 4 : Litopenaeus stylirostris. Survival rate (mean \pm SD), percentage of PL3/PL4 stage (mean $\pm \mathrm{SD}$ ) and dry weight (mean $\pm \mathrm{SD}$ ) according to postlarval rearing salinity.

\begin{tabular}{lcc}
\hline Treatment & $35-27$ & $35-35$ \\
\hline Number of replicates & 4 & 4 \\
Survival rate at D19 (\%) & $56.6 \pm 21.4$ & $47.6 \pm 17.7$ \\
Percentage of PL4 (\%) & $72.5 \pm 5.1$ & $45.7 \pm 19.3$ \\
Mean dry weight at D19 (mg) & $0.24 \pm 0.05$ & $0.20 \pm 0.06$ \\
\hline
\end{tabular}




\section{Figures}

Figure 1 : Litopenaeus stylisrostris. Survival rates at 6 and $24 \mathrm{hrs}$ according to the media osmolality and the developmental stages $(A-F)$. Values are means $\pm S D(n=3)$. Different letters indicate significant differences between survival $(p<0.05)$ at $24 \mathrm{hrs}$.

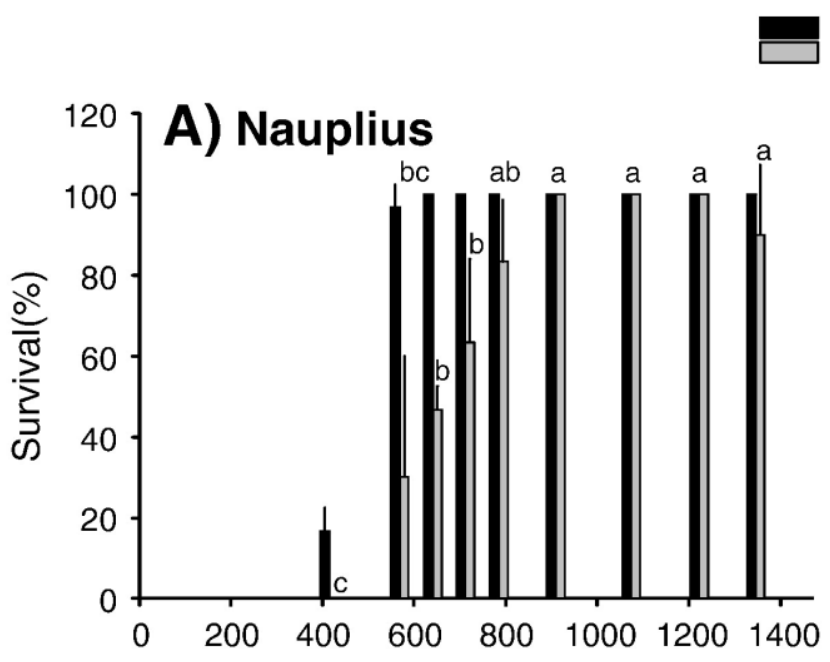

6 hrs

$4 \mathrm{hrs}$
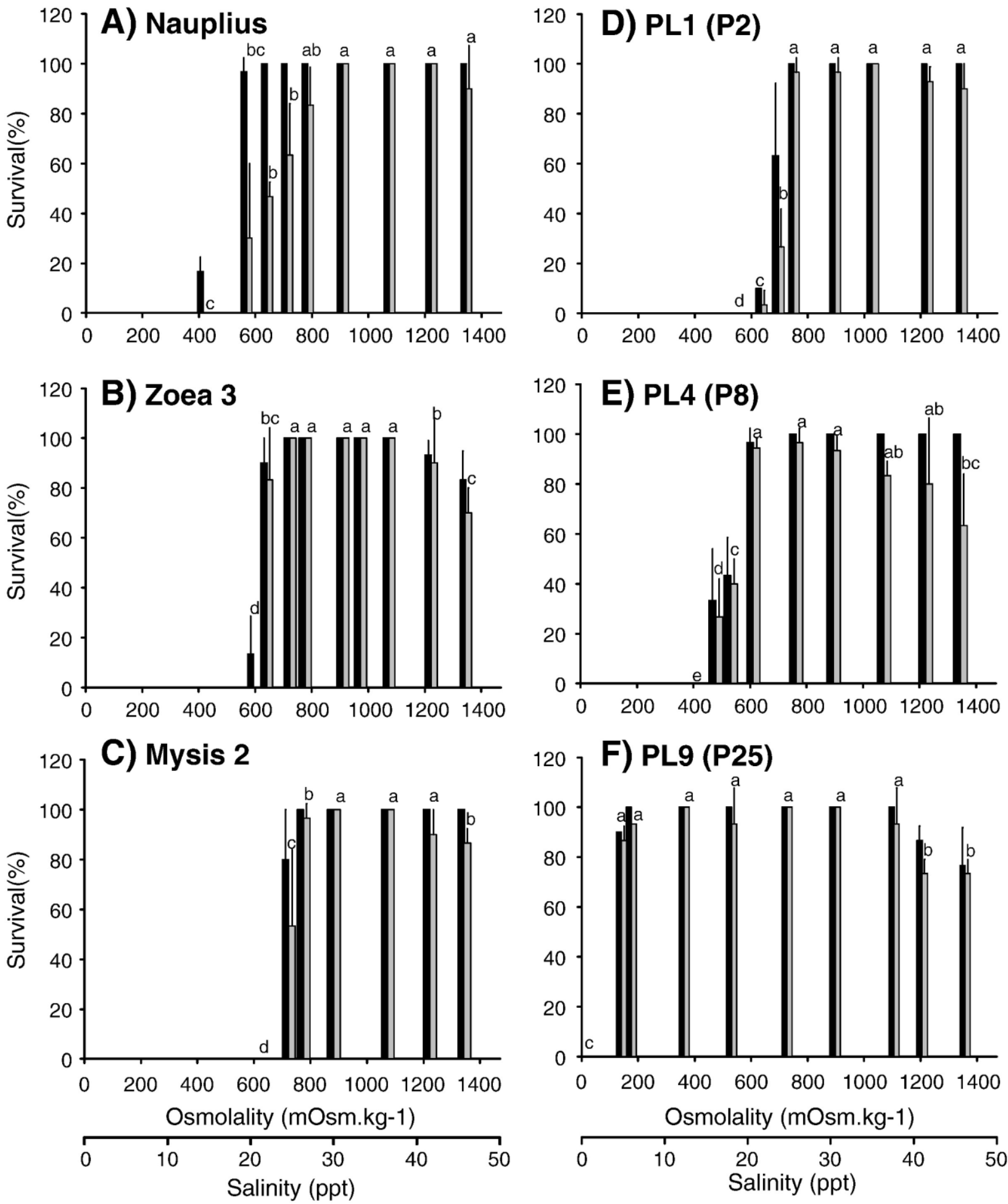
Figure 2 : Litopenaeus stylisrostris. Lethal salinity for $50 \%$ of animals at $24 \mathrm{hrs}$ according to the development stage. Nii: nauplii, Z: zoea, M:mysis, PL: post-larvae.

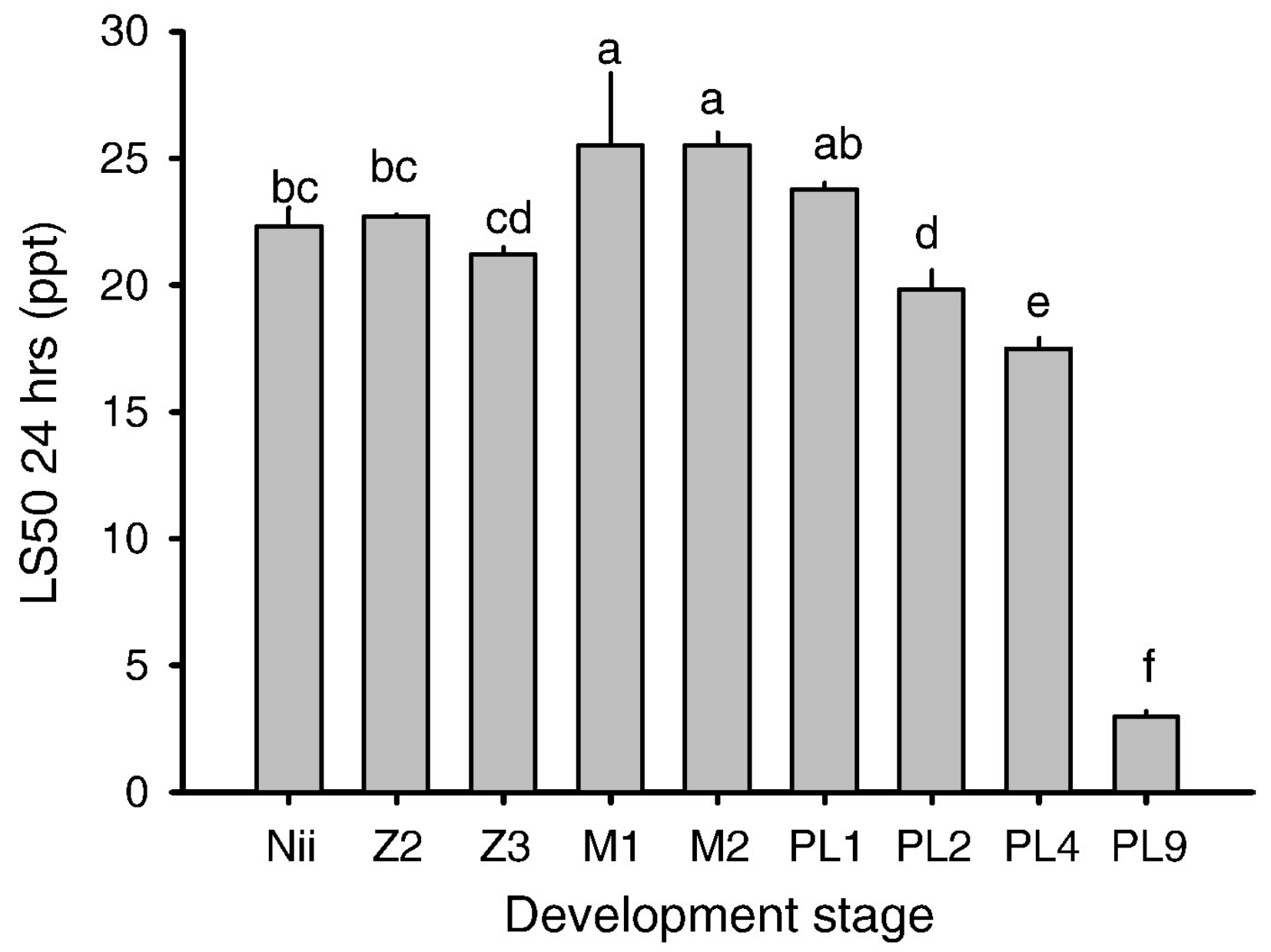


Figure 3 : Litopenaeus stylisrostris. A: Variations of hemolymph osmolality in selected stages of development in relation to the osmolality of the external medium; diagonal dashed line: isosmotic line. Values are means $\pm S D(n=3$ to 10). B: Variations in osmoregulatory capacity at different stages of development in relation to the osmolality of the external medium. Values are means $\pm S D(n=3$ to 10). Different letters indicate significant differences between osmoregulatory capacity $(p<0.05)$ for each stage.

A

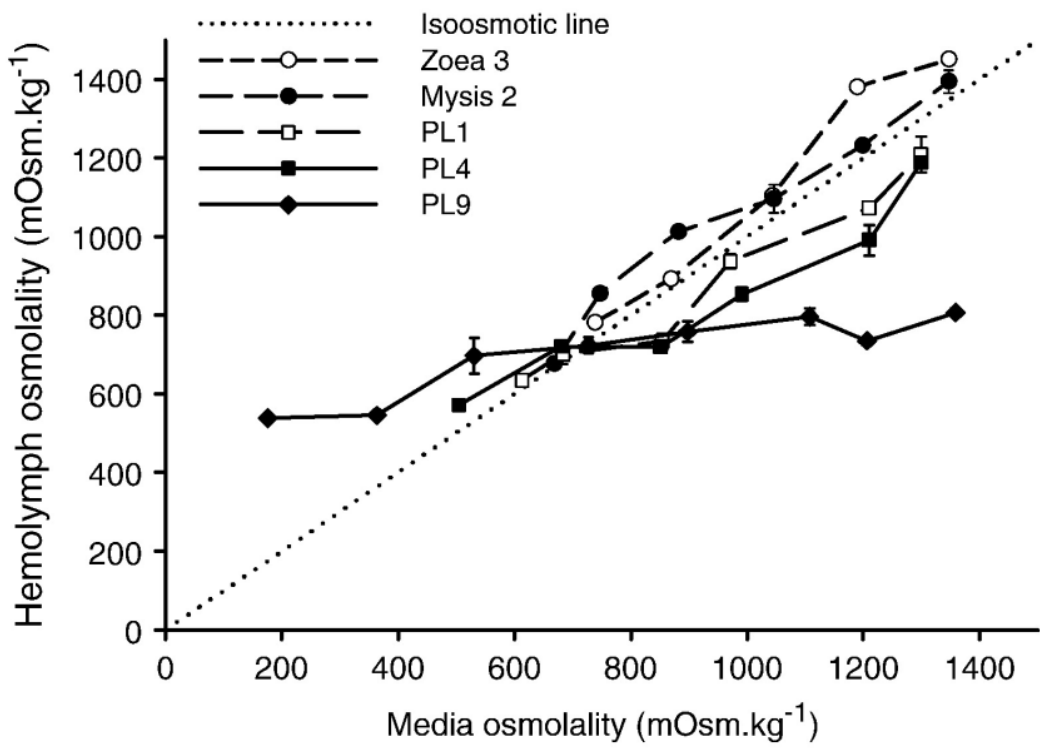

B
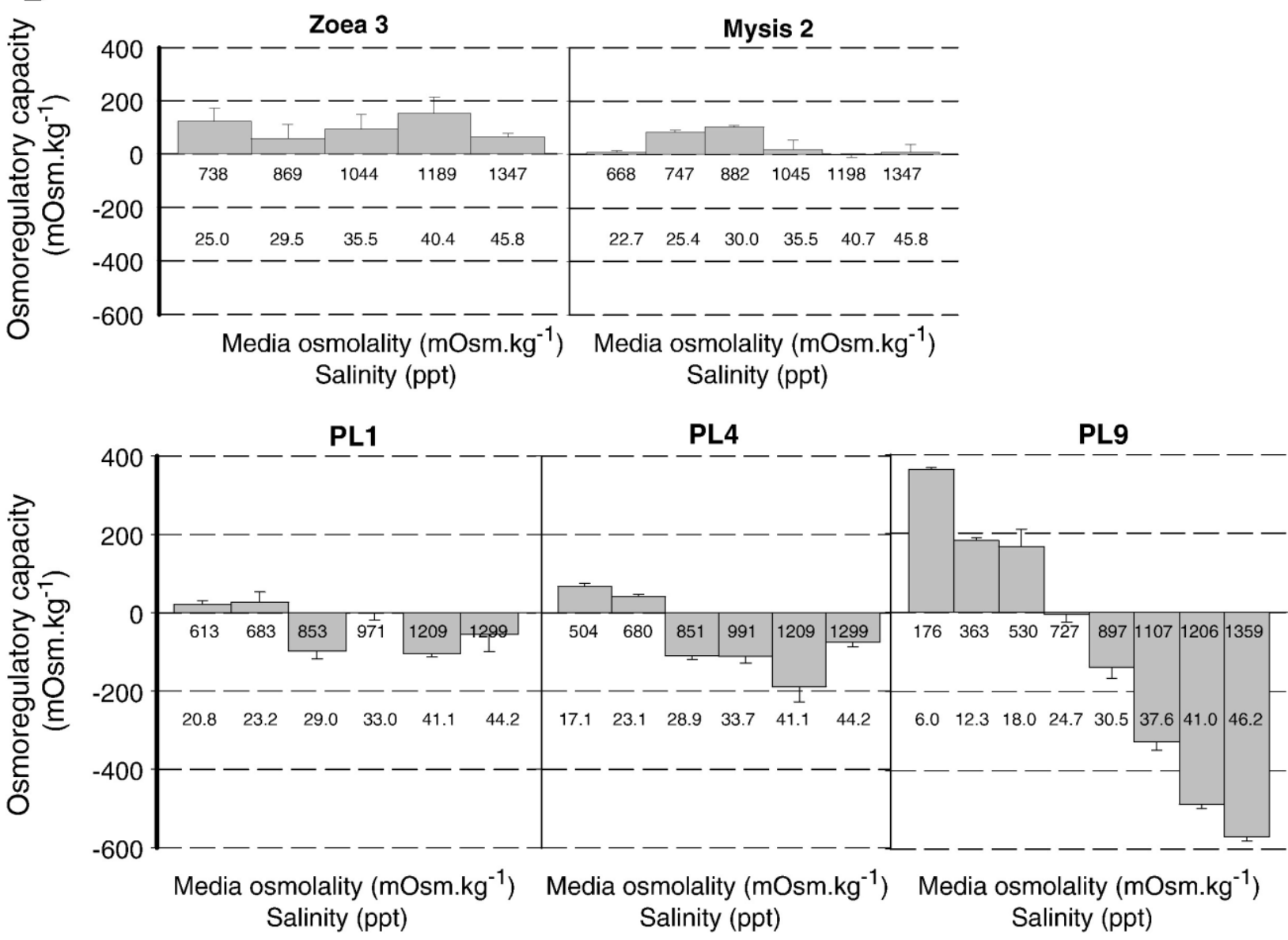
Figure 4 : Litopenaeus stylisrostris. Evolution of survival rate according to the rearing day (D) after direct transfer of nauplii from $39 \mathrm{ppt}$ to different experimental salinities.

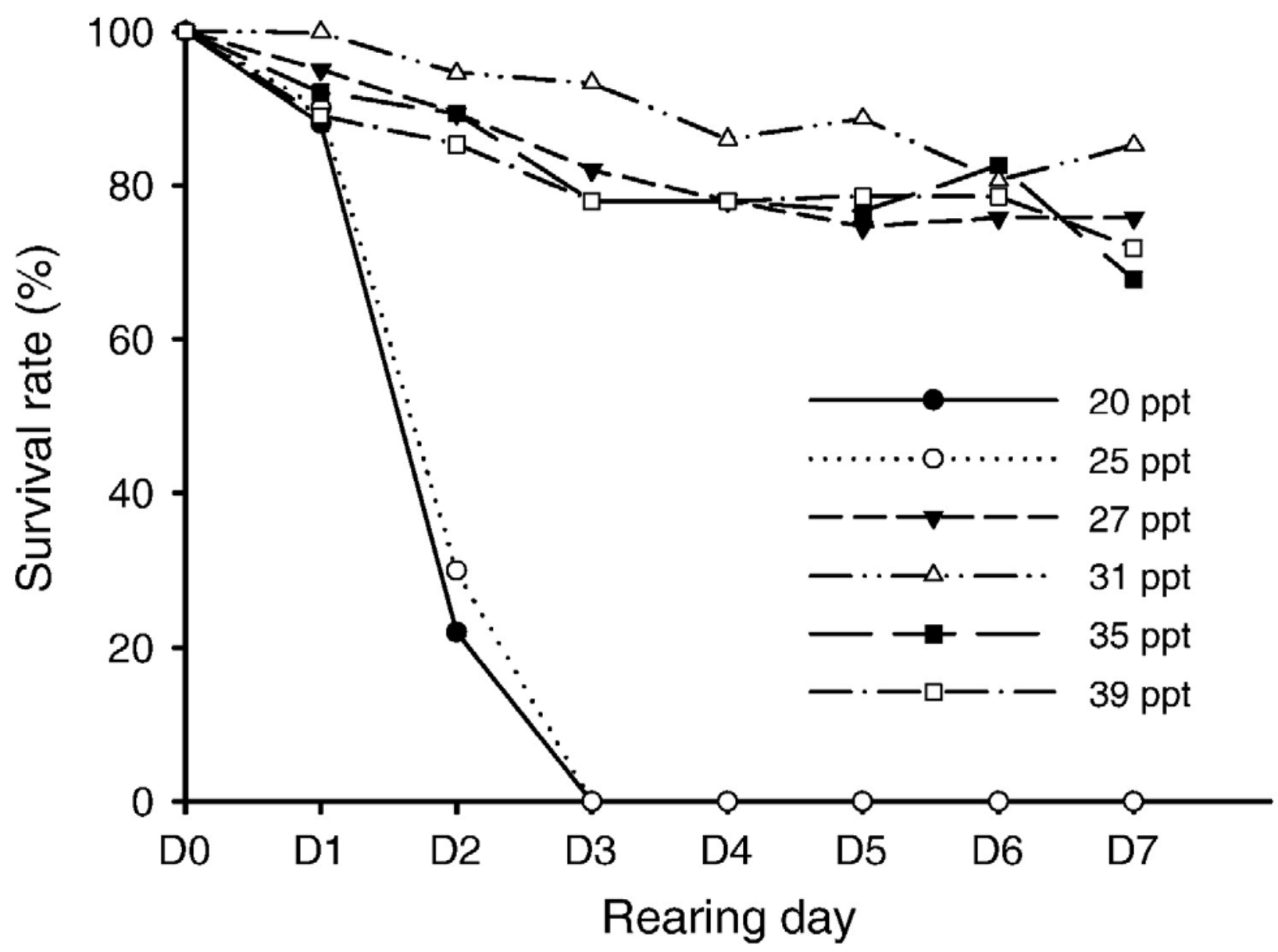


Figure 5 : Litopenaeus stylisrostris. Survival rate (S\%)and the development index (DI) according to two rearing salinities (30 and $35 \mathrm{ppt}$ ) during the larval phase. * indicates significant differences between rearing salinities.

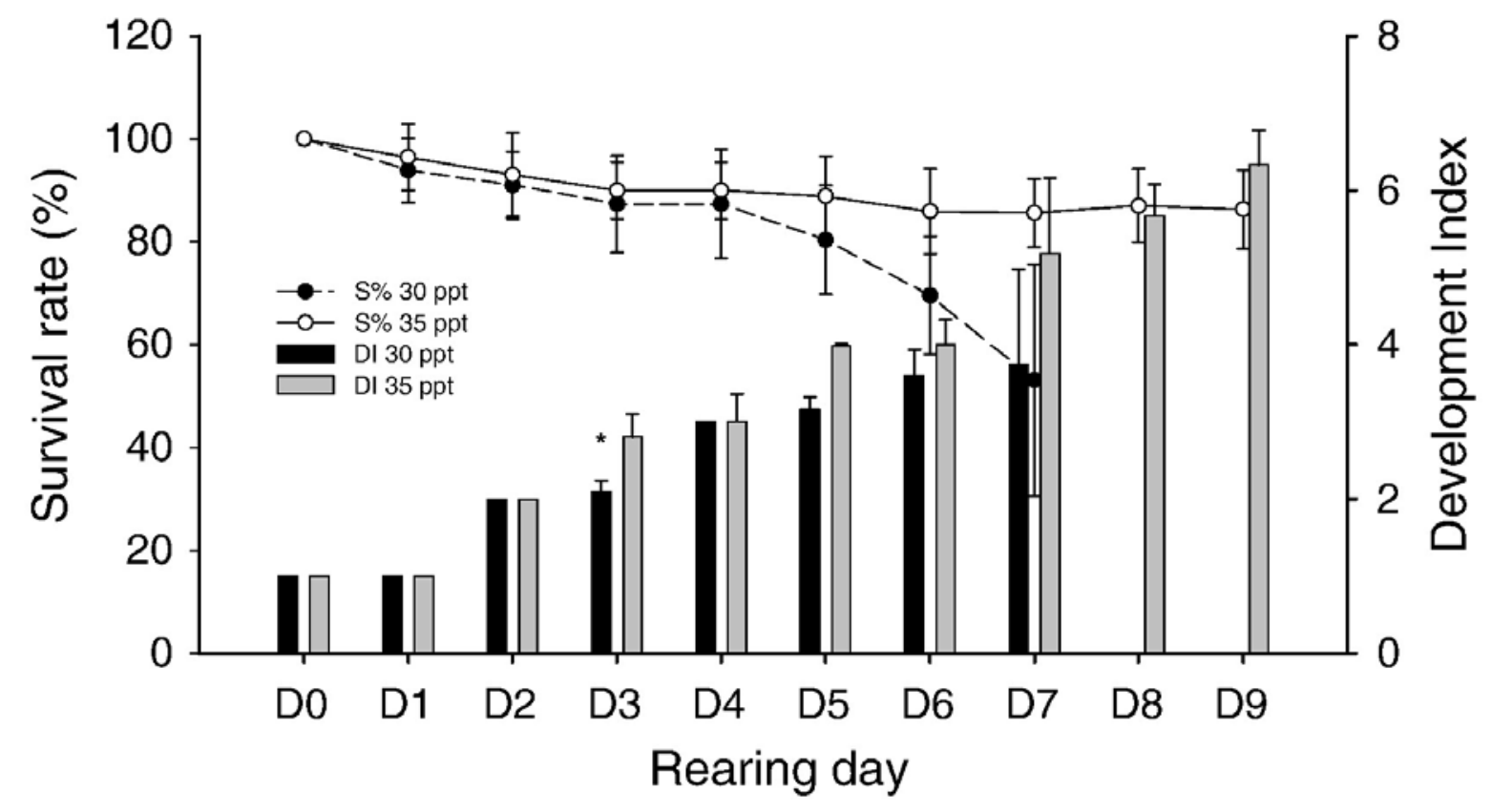

Figure 6 : Litopenaeus stylisrostris. Percent of postlarvae at PL5 stage or beyond and mean dry weight of postlarvae at the end of the larval rearing (32 days) after exposure to different culture conditions. 35-27-27: day 0 to 9 at 35 ppt, day 9 to 32 at 27 ppt; 35-35-27: day 0 to 19 at $35 \mathrm{ppt}$, day 19 to 32 at $27 \mathrm{ppt}$; 35-35-35: day 0 to 32 at 35 ppt. Bars sharing different letters are significantly different $(p<0,05)$.

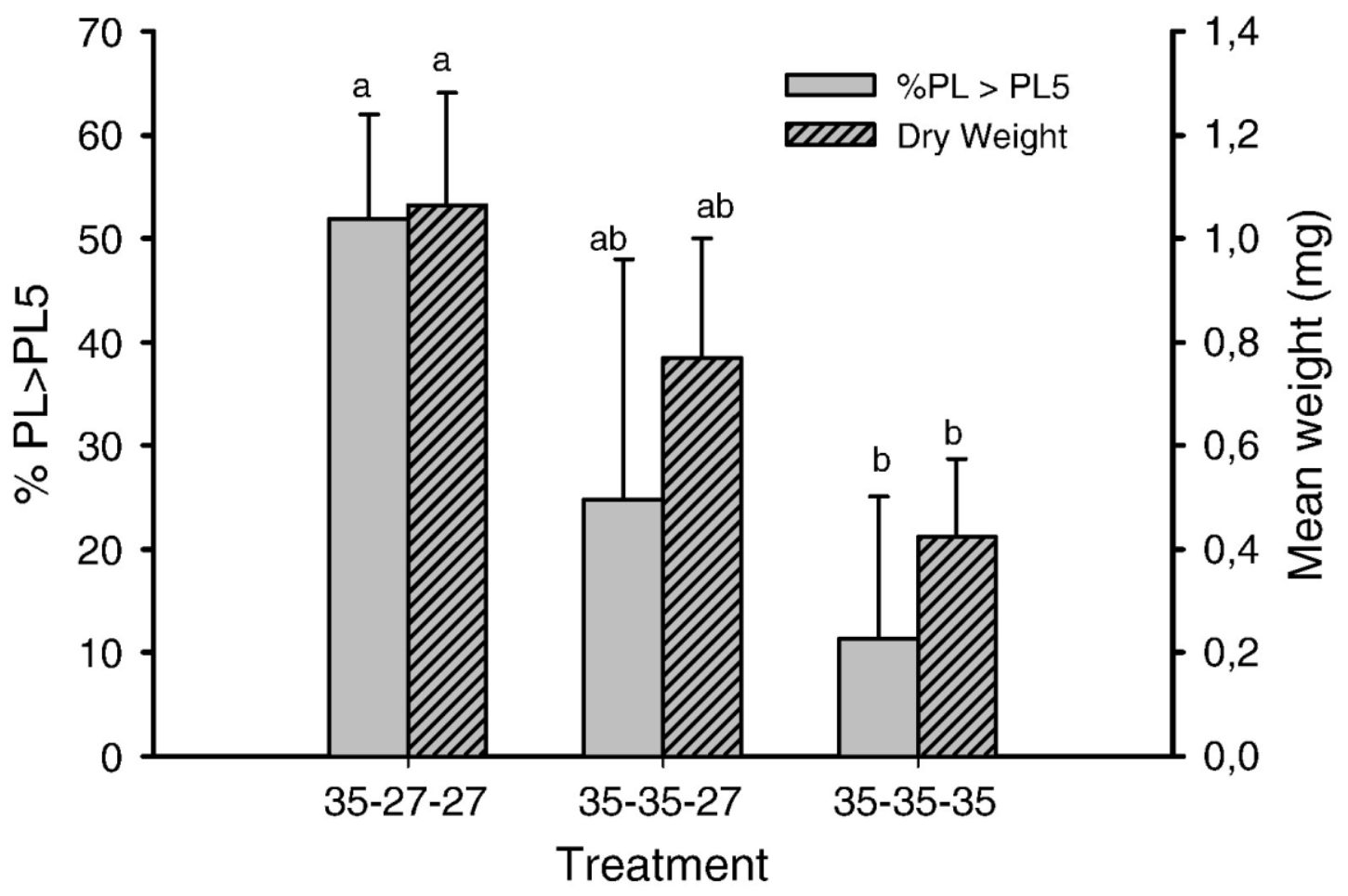




\section{List of symbols and abbreviations}

6 h LS50 : Lethal salinities for $50 \%$ of animals at 6 hours $24 \mathrm{~h} \mathrm{LS50}$ : Lethal salinities for $50 \%$ of animals at 24 hours OC : Osmoregulatory Capacity

PBS : Phosphate-Buffered Saline

PLi : Postlarvae on stage i

$\mathrm{Pj}$ : j day-old postlarvae after metamorphosis

ppt : part per thousand

RF : Rostral Formulae 